\title{
MENINGKATKAN HASIL BELAJAR LISTRIK DINAMIK MENGGUNAKAN STRATEGI PEMBELAJARAN TEAM ASSISTED INDIVIDUALIZATION MELALUI SIMULASI CROCODILE PHYSICS
}

\author{
Ahmad Gumrowi \\ MAN 1 Bandar Lampung, Indonesia; e-mail: gumrowi@gmail.com \\ Diterima: 11 Februari 2016. Disetujui: 5 April 2016. Dipublikasikan: April 2016
}

\begin{abstract}
This study aims to improve the learning outcomes on dynamic electric of MAN 1 Bandar Lampung's students using Cooperative Learning Model, Team Assisted Individualization (TAI) type, through crocodile physics simulation. The object of this study is the result of students' learning on the subject of electric dynamic using cooperative learning model type TAI (team assisted individualization) through physics crocodile simulation. This study was conducted in three cycles. The results of analysis show that cooperative learning strategies type Team Assisted Individualization through crocodile physics simulations can improve learning outcomes on dynamic electricity. The average of students' learning outcomes increased as follows: the first cycle is 61.23, and 68.13 in the second cycle, an increase of 11.27\%, and the third cycle result is 72.63 , or an increase of $6.6 \%$.
\end{abstract}

\begin{abstract}
Abstrak: Penelitian ini bertujuan untuk meningkatkan hasil belajar listrik dinamik siswa MAN 1 Bandar Lampung dengan menggunakan model pembelajaran kooperatif tipe Team Assisted Individualization (TAI). melalui simulasi Crocodile physics. Objek penelitian ini adalah hasil belajar siswa pada pokok bahasan listrik dinamik dengan model pembelajaran kooperatif Tipe TAI (team assisted individualization) melalui simulasi Crocodile physics. Penelitian ini dilaksanakan selama tiga siklus, dari hasil analisis diperoleh bahwa strategi pembelajaran kooperatif tipe Team Assisted Individualization melalui simulasi crocodile physics dapat meningkatkan hasil belajar listrik dinamik. Rata-rata hasil belajar siswa meningkat pada siklus I dari 61,23 menjadi 68,13 pada siklus II atau meningkat $11,27 \%$, pada siklus III 72,63 atau meningkat $6,6 \%$
\end{abstract}

(C) 2016 Pendidikan Fisika FTK IAIN Raden Intan Lampung

Kata Kunci: cooperatif tipe TAI, listrik dinamik, simulasi crocodile physics.

\section{PENDAHULUAN}

Pada akhir-akhir ini kualitas pendidikan di Indonesia banyak mengalami sorotan, baik dari kalangan pemerintah, swasta ataupun kalangan insan pendidikan sendiri (Yuniar, 2013). Hal ini disebabkan dengan rendahnya perolehan nilai ujian siswa yang merupakan indikator pencapaian hasil belajar (Sulistyo, 2007). Salah satu mata pelajaran yang termasuk kategori rendah adalah fisika, tinggi rendahnya hasil belajar fisika siswa disebabkan oleh beberapa faktor.

Banyak komponen yang mempengaruhi hasil belajar seorang siswa yaitu: (1) guru, (2) kurikulum, (3) siswa, (4) media, (5) metode mengajar, dan (6) lingkungan (Kholid, 2013). Berdasarkan hasil prapenelitian beberapa penyebab rendahnya hasil belajar yaitu pemilihan metode dan media pembelajaran yang digunakan oleh guru pada proses pembelajaran sangat kurang tepat dan pengelolaan kegiatan pembelajaran yang masih belum dapat membangkitkan motivasi belajar siswa secara optimal.

Pembelajaran tipe Team Assisted Individualization merupakan pembelajaran yang menggabungkan belajar kooperatif dengan individu (Hermawan, Paloloang, \& Sukayasa, 2014; Tinungki, 
2015). Dalam menyelesaikan tugas kelompok, masing-masing anggota kelompok bertanggung jawab terhadap keberhasilan kelompoknya karena keberhasilan kelompok ditentukan oleh masing-masing anggota kelompok, dalam hal ini setiap anggota kelompok harus bekerja sama dan saling membantu untuk saling memahami materi pelajaran. Pelajaran belum dapat dilanjutkan jika salah satu anggota belum menguasai pelajaran (Slavin, 1995; Tilaar, 2014; Vitria \& Utami, 2014).

Simulasi crocodile physics adalah media pembelajaran simulasi berbasis TIK, merupakan software pembelajaran virtua lab yang dignuakan sesuai kebutuhan (Lindgren \& Schwartz, 2009; Muhammad \& Pintauli, 2014a) dapat didownload di www.crocodile-clips.com.

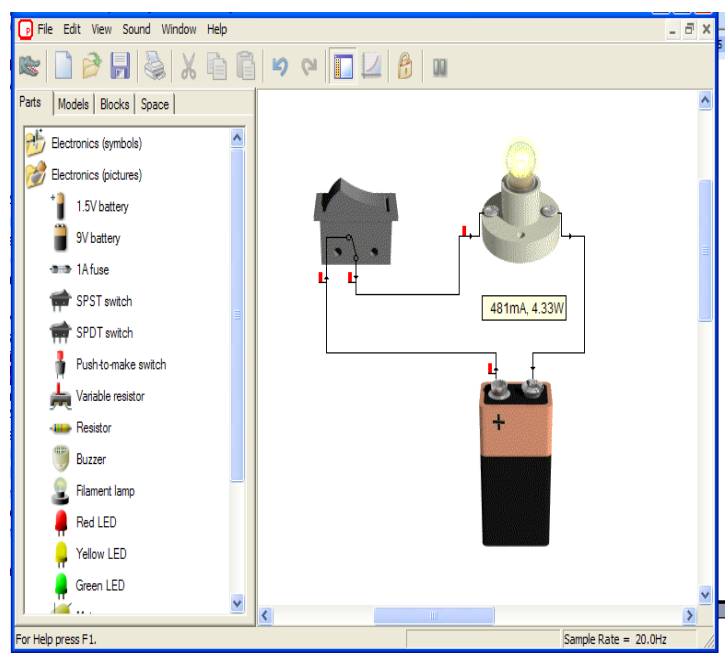

Gambar 1. Tampilan Crocodile Physics Sumber: (Team, n.d.)

Pada penelitian tindakan kelas ini peneliti mencoba mengkolaborasikan antara strategi pembelajaran kooperatif tipe Team Assisted Individualization (TAI) dan media simulasi crocodile physics. Dengan menggunakan model pembelajaran TAI dan media simulasi crocodile physics siswa diharapkan akan tertarik dan termotivasi sehingga siswa aktif mengikuti kegiatan belajar mengajar, dengan demikian hasil belajar fisika siswa akan meningkat.

Penelitian ini sejalan dengan apa yang telah dilakukan oleh (Muhammad \& Pintauli, 2014b) menunjukkan bahwa media Crocodile Physics memberikan hasil belajar yang lebih baik dibandingkan dengan media gambar di papan tulis pada pembelajaran virtual di sekolah.

Selain itu hasil penelitian yang lakukan oleh (Budi, Edhi, \& Sukisno, 2014) tentang Implementasi Model Pembelajaran Physics-Edutainment Dengan Bantuan Media Crocodile Physics Pada Mata Pelajaran Fisika menunjukan bahwa penerapan pembelajaran PhysicsEdutainment dengan media simulasi Crocodile Physics memberikan hasil belajar yang lebih baik daripada pembelajaran Physics- Edutainment yang dipadukan dengan ceramah. Pengembangan pengajaran PhysicsEdutainment ini diharapkan dapat membuat proses pengajaran fisika lebih baik.

Tujuan penelitian ini adalah untuk meningkatkan hasil belajar listrik dinamik siswa MAN 1 Bandar Lampung dengan menggunakan model pembelajaran kooperatif tipe Team Assisted Individualization (TAI) melalui simulasi Crocodile Physics. Pembaharuan dadri penelitian sebelumnya Crocodile Physics digunakan dengan model TAI. Manfaat dari penelitian ini sebagai informasi bagi guru mengenai alternatif metode belajar yang dapat diterapkan dalarn kegiatan pembelajaran di kelas dan dapat membimbing siswa untuk Iebih aktif dalam proses pembelajaran.

\section{METODE PENELITIAN}

Penelitian ini dilakukan di MAN 1 Bandar Lampung yang berlokasi di Jl. Letkol. H. Endro Suratmin, Kel. Korpri Jaya Kec. Sukarame Bandar Lampung.

Penelitian tindakan ini dilaksanakan 3 siklus, berlangsung selama satu bulan. Rincian Prosedur Penelitian pada tiap-tiap 
siklus terdiri dari empat tahapan, yaitu: 1) Perencanaan (planning); 2) Pelaksanaan tindakan (acting); 3) Pengamatan (observasing); 4) Refleksi berdasarkan hasil pengamatan (reflecting). Keempat tahap merupakan sebuah siklus, yaitu satu putaran kegiatan beruntun yang kembali ke langkah semula . (Kemmis dan Taggart dalam (Kunandar, 2008).

Pada tahap persiapan peneliti menyesuaikan dengan jadwal mengajar peneliti, menyusun instrumen pembelajaran seperti RPP, bahan ajar, download software crocodile physics, memilih metode pembelajaran yang digunakan yakni Pembelajaran kooperatif tipe TAI (team asissisted individualization) dan mendata siswa yang memiliki laptop.

Siklus pertama dilaksanakan dua kali pertemuan, begitu juga siklus kedua dan ketiga. Setelah tindakan perbaikan pembelajaran dilaksanakan pada masingmasing siklus selanjutnya dilakukan kegiatan observasi dan hasilnya dianalisis dan dilakukan refleksi guna mengetahui tingkat keberhasilan atau kegagalannya.

Kegiatan awal peneliti membagi kelompok belajar berdasarkan nilai preetest. Kemudian berdasarkan nilai preetest siswa dibagi menjadi 6 kelompok heterogen terdiri dari 5 siswa Sebelum guru memulai menyampaikan materi pelajaran tentang terlebih dahulu menjelaskan tujuan pembelajaran dan membahas materi prasyarat. Peneliti menjelaskan bagaimana proses pembelajaran kooperatif tipe TAI dan menjelaskan simulasi crocodile physics.

Kegiatan inti, peneliti menjelaskan secara singkat materi pelajaran dengan simulai crocodile physics, dilanjutkan dengan belajar kelompok. Untuk mengantisipasi jika siswa kurang memahami software merasa bingung dengan model pembelajaran ini maka peneliti memberikan tutorial terlebih dahulu. Menjelang akhir pembelajaran perwakilan kelompok disuruh mempresentasikan apa yang telah dipelajari.

Kegiatan akhir, peneliti bersama siswa menyimpulkan hasil belajar, memberikan, penghargaan kepada kelompok yang aktif kemudian memberikan pada akhir pertemuan kedua setiap siklus, peneliti memberikan tes tertulis.

Hasil analisis dan refleksi digunakan sebagai bahan perbaikan tindakan pada siklus berikutnya. Analisis data hasil belajar diambil rata-rata nilai tes yang diberikan setelah mengikuti proses kegiatan pembelajaran dengan menggunakan pembelajaran kooperatif tipe TAI (Team Assisted Individualizaüon) dalam setiap siklus digunakan rumus (Aqib, 2010 dalam (Pasaribu, 2015).

$\bar{X}=\frac{\Sigma N S}{N}$

Keterangan

$\bar{X} \quad$ : Nilai rata-rata tes

$\Sigma N S \quad$ : Jumlah nilai seluruh siswa

$\mathrm{N}$ : Jumlah siswa

Indikator keberhasilan dapat dilihat dari peningkatan hasil belajar siswa, jika jumlah siswa yang aktif dan nilai rataratanya meningkat dari siklus I sampai dengan siklus III, maka proses pembelajaran dikatakan berhasil. Indikator berpedoman kepada indikator sebagai berikut:

Siswa dapat menyelesaian kasus tentang Listrik Dinamik. Siswa paham tentang materi yang disampaikan dengan pencapaian $75 \%$ siswa dapat tuntas pada kompetensi dasar yang diberikan. Kategori tentang keberhasilan siswa dengan nilai hasil test $\geq 70$ sesuai dengan KKM.

\section{HASIL DAN PEMBAHASAN}

Software Crocodile Physics merupakan program yang dikembangkan oleh Crocodile Company yang menyediakan lingkungan laboratorium untuk mata pelajaran fisika untuk siswa menengah. Dengan dukungan 
Pembelajaran kooperatif tipe TAI (team asissisted individualization) siswa dibawa

Hasil penelitian diperoleh data hasil belajar sebagai berikut:

Tabel.1 Data hasil belajar 31 siswa

\begin{tabular}{|l|c|l|l|l|}
\hline \multirow{2}{*}{ Kegiatan } & \multicolumn{2}{|l|}{$\begin{array}{l}\text { Ketuntasan } \\
\text { Klasikal (\%) }\end{array}$} & $\begin{array}{l}\text { Rerata } \\
\text { Hasil } \\
\text { Belajar }\end{array}$ & $\begin{array}{l}\text { \% } \\
\text { Kenaikan } \\
\text { Siswa } \\
\text { Belajar }\end{array}$ \\
\hline $\begin{array}{l}\text { Pra } \\
\text { Siklus }\end{array}$ & 6 & 20,00 & 55,83 & \\
\hline Siklus I & 10 & 33,33 & 61,23 & 9,67 \\
\hline Siklus II & 20 & 66,67 & 68,13 & 11,27 \\
\hline Siklus III & 25 & 83,33 & 72,63 & 6,60 \\
\hline
\end{tabular}

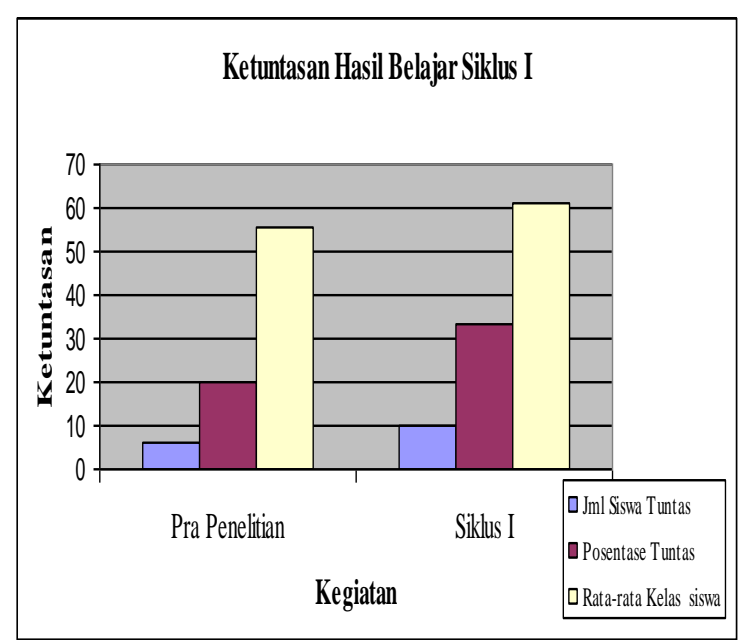

Gambar 2. Ketuntasan Hasil Belajar pada siklus I

Berdasarkan data hasil tes pada tabel 1 dan gambar 2 menunjukkan bahwa siswa yang memperoleh nilai $\geq 70$ (tuntas) sebanvak 10 siswa atau sekitar 33,33\% dari jumlah siswa yang hadir. Jika dibandingkan dengan nilai awal siswa yang berjumlah 6 siswa atau 20\% jelas mengalami peningkatan $66,67 \%$. Sedangkan rata-rata hasil belajar dari 55,83 menjadi 61,23 atau meningkat 9,67\% dari sebelum menggunakan TAI. Kenaikan masih sangat jauh dari harapan peneliti, tetapi jelas adanya perubahan hasil belajar siswa dengan perlakuan model TAI melaui simulasi crocodile physics.

Dari analisis pada siklus I, tindakan positif yang telah dilakukan oleh peneliti pada siklus I sebagai berikut:

1. Menyusun Rencana Pelaksanaan Pembelajaran (RPP)

2. Menjelaskan tujuan pembelajaran

3. Menjelaskan tentang model pembelajaran yang akan dikembangkan

4. Membagi siswa secara homogen ke dalam kelompok-kelompok kecil berdasarkan nilai uji blok materi pada bab yang terdahulu.

5. Menjelaskan materi secara ringkas

6. Dibantu oleh siswa menginstal software crocodile physics

7. Menjelaskan cara menggunakan software crocodile physics

Pada penelitian diidentifikasi beberapa hal yang menyebabkan hasil belajar siswa kurang baik yaitu:

1. Guru/peneliti belum optimal dalam memotivasi siswa untuk belajar.

2. Guru/peneliti kurang tegas dalam pembagian kelompok belajar.

3. Pada masing-masing kelompok baru ada satu laptop/komputer, sedangkan jumlah perkelompok 5 siswa.

4. Guru/peneliti kurang memperhatikan pemahaman pada siswa tentang pentingnya kerjasama dalam kelompok untuk menyelesaikan suatu masalah.

5. Sebagian besar siswa belum memahami cara menggunakan software crocodile physics.

6. Sebagian besar siswa ribut merasa takjub dengan software crocodile physics sehingga tidak memperhatikan penjelasan guru.

Tindakan perbaikan yang harus dilakukan pada siklus I adalah sebagai berikut:

1. Guru hendaknya menjelaskan lebih rinci tujuan pembelajaran yang akan 
dilakukan kepada siswa, sehingga siswa akan lebih termotivasi.

2. Dalam pembagian atau pembentukan kelompok belajar, guru seharusnya bertindak tegas.

3. Perlunya latihan menggunakan software crocodile physics sebelum prose pembelajaran.

4. Guru menjelaskan kembali kepada siswa tentang pentingnya belajar kelompok dan mengarahkan siswa untuk lebih aktif dalam berdiskusi maupun bertanya kepada guru atau siswa jika tidak mengerti terhadap materi yang diajarkan.

5. Peneliti harus lebih aktif mengwasi kelompok belajar.

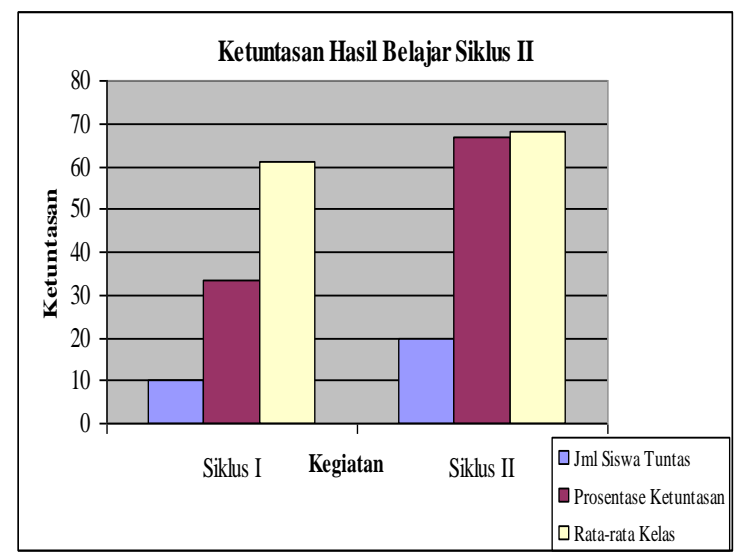

Gambar 3. Ketuntasan Hasil Belajar pada Siklus II

Pada siklus II terlihat adanya peningkatan hasil belajar siswa. Peningkatan ini disebabkan aktivitas siswa baik secara kelompok meupun individu mengalami peningkatan yang signifikan. Ini tidak terlepas dari pengelolaan pembelajaran oleh guru/peneliti.

Pada siklus II siswa yang tuntas atau memperoleh nilai $\geq 70$ sebanyak 20 siswa atau $66,67 \%$ dari jumlah siswa yang hadir. Sedangkan hasil belajar rata-rata kelas 68,13. Jika dibandingkan dengan siklus I mengalami kenaikan $100 \%$. Walaupun hasil belajar mengalami peningkatan yang cukup baik pada siklus II namun indikator keberhasiIan siswa baik secara individu maupun klasikal belum terpenuhi.
Pada siklus II tindakan positif yang telah dilakukan oleh peneliti sebagai berikut:

1. Memperbaiki Rencana Pelaksanaan Pembelajaran (RPP)

2. Menjelaskan lebih rinci tujuan pembelajaran

3. Mengingatkan kembali materi pada pertemuan sebelumnya

4. Menjelaskan kembali tentang model pembelajaran yang akan dikembangkan dan kerja sama kelompok.

5. Menjelaskan materi secara ringkas

6. Mengontrol siswa yang belum bisa memakai software crocodile physics

Beberapa hal yang menyebabkan aktivitas dan hasil belajar siswa kurang baik pada pertemuan 1 siklus II yaitu:

1. Guru/peneliti belum optimal dalam memotivasi siswa untuk belajar.

2. Guru/peneliti tidak menegur siswa yang tidak ikut aktif pada kelompoknya kelompok bclajar.

3. Masih ada beberapa siswa ribut dan asyik dengan bermain laptop dan tidak memperhatikan penjelasan guru.

4. Ada bebarapa siswa yang online mencari informasi lain

5. Masih ada beberapa siswa kurang aktif dalam diskusi kelompok maupun bertanya dengan teman jika tidak mengerti terhadap materi yang diajarkan.

Adapun perbaikan yang harus dilakukan pada siklus II antara lain

1. Guru selalu mengamati aktivitas siswa dalarn proses pelaksanaan diskusi atau belajar kelompok agar aktivitas siswa lebih baik.

2. Guru lebih sering membimbing dan sabar dalam membimbing siswa yang daya tangkap atau pemahamannya lemah pada materi pembelajaran.

3. Guru meminta petugas sever untuk mematikan hotspot. 
4. Guru meminta siswa yang membawa modem untuk dikumpul sementara sampai pembelajaran berakhir

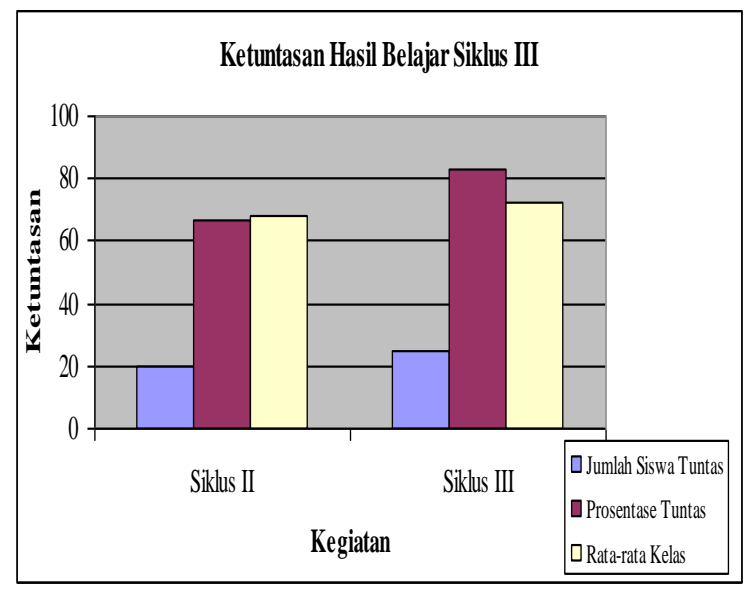

Gambar 4. Ketuntasan Hasil Belajar pada siklus III

Pelaksanaannya siklus III berdasarkan rujukan refleksi siklus II. Apabila hasil yang ada belum mencapai indikator keberhasilan yang ditetapkan, maka penelitian masih tetap dilanjutkan sampai indikator yang diharapkan tercapai. Tahapan pada siklus ini juga sama, namun pada akhir siklus III jika hasil test sesuai dengan indikator yang diharapkan maka penelitian ini dihentikan.

Pada siklus III siswa yang memperoleh nilai $\geq 70$ sebanyak 25 siswa atau $83,33 \%$ meningkat $25 \%$ dari siklus II dengan rata-rata kelas 72,63 . atau meningkat $6,6 \%$ dari rata-rata siklus II.

Dengan melihat perubahan-perubahan ini jelaslah bahwa bahwa strategi pembelajaran kooperatif tipe Team Assisted Individualization melalui simulasi crocodile physics dapat meningkatkan hasil belajar listrik dinamik siswa MAN 1 Bandar Lampung secara signifikan.

Hasil ketuntasan belajar yang peneliti lakukan tidak jauh berbeda dengan hasil uji ketuntasan belajar oleh (Budi et al., 2014) tentang Implementasi Model Pembelajaran Physics-Edutainment Dengan Bantuan Media Crocodile Physics Pada Mata Pelajaran Fisika menunjukan bahwa penerapan pembelajaran PhysicsEdutainment dengan media simulasi Crocodile Physics diperoleh persentase ketuntasan belajar klasikal untuk kelompok eksperimen sebesar $85 \%$ dan kelompok kontrol sebesar $68 \%$. Hasil belajar psikomotorik dinilai pada pelaksanaan praktikum. Hasil belajar psikomotorik rata-rata kelas eksperiman sebesar 79,49, sedangkan rata-rata kelas kontrol sebesar 71,67. Hasil belajar afektif dilihat dari penilaian observer dimana ratarata hasil aspek afektif kelas eksperimen sebesar 81,39 dan kelas kontrol sebesar 78,06

Demikian juga hasil penelitian yang dilakukan oleh Fitri Mawaddah Lubis,Nurdin Bukit, Harahap (2015) tentang Efek Model Pembelajaran Kooperatif Tipe Nht (Numbered Heads Together) Menggunakan Media Simulasi Phet Dan Aktivitas Terhadap Hasil Belajar Siswa menyatakan bahwa nilai hasil belajar fisika siswa yang menggunakan model pembelajaran kooperatif tipe NHT menggunakan media simulasi PhET adalah 83,20 dengan standar deviasi 11,07 sedangkan siswa yang menggunakan model pembelajaran konvensional adalah 73,06 dan standar deviasi 11,78. Berdasarkan hasil hipotesis diperoleh bahwa hasil belajar siswa yang dibelajarkan menggunakan pembelajaran kooperatif tipe NHT lebih baik dibandingkan hasil belajar siswa yang dibelajarkan dengan pembelajaran konvensional.

\section{SIMPULAN}

Berdasarkan hasil penelitian dan pembahasan dapat diambil kesimpulkan Strategi Pembelajaran kooperatif tipe TAI (Team Assisted Individualization) melalui simulasi crocodile physics dapat meningkatkan hasil belajar listrik dinamik siswa MAN 1 Bandar Lampung pada setiap siklusnya. Rata-rata hasil belajar siswa meningkat pada siklus I dari 61,23 menjadi 68,13 pada siklus II atau 
meningkat $11,27 \%$, pada siklus III 72,63 atau meningkat $6,6 \%$

\section{DAFTAR PUSTAKA}

Budi, R., Edhi, S. ., \& Sukisno, M. (2014). Implementasi Model Pembelajaran Physic-Edutainment dengan Bantuan Media Crocodile Physics Pada Mata Pelajaran Fisika. Journal Unnes, 3(1), 30-36.

Hermawan, H., Paloloang, B., \& Sukayasa. (2014). Penerapan Model Pembelajaran Kooperatif Tipe Team Assisted Individualization ( TAI ) Untuk Meningkatkan Hasil Belajar Siswa Kelas V SDN 4 Bajugan Pada Operasi Hitung Campuran. Jurnal Kreatif Tadulako Online, 4(9), 44-60.

Kholid, M. (2013). Problematika pendidikan di indonesia. Edu-Bio, 4, 51-57.

Kunandar. (2008). Langkah Mudah Penelitian Tindakan Kelas. Jakarta: PT. Raja Grafindo Persada.

Lindgren, R., \& Schwartz, D. L. (2009). Spatial Learning and Computer. International Journal of Science Education, 31(3), pp.419-438. https://doi.org/10.1080/09500690802 595813

Muhammad, H., \& Pintauli, S. (2014a). Pengaruh Penggunaan Media Pembelajaran Terhadap Hasil Belajar Dasar-dasar Kelistrikan (DDK). Jurnal Pendidikan Teknologi Dan Kejuruan, 4(1).

Muhammad, H., \& Pintauli, S. (2014). Pengaruh Penggunaan Media Pembelajaran Terhadap Hasil Belajar Dasar-Dasar Kelistrikan (DDK) Kelas X Program Keahlian Teknik Instalasi Tenaga Listrik (TITL) SMK Negeri 1 Lubuk Pakam. Jurnal Pendidikan Teknologi Dan Kejuruan, 16(2), 73-94.

Pasaribu, E. (2015). Meningkatkan Hasil Belajar dengan Metode Contextual Teaching Learning pada Mata Pelajaran Sejarah. Jurnal Pendidikan
Ilmu-Ilmu Sosial, 7(1), 13-19.

Slavin, R. (1995). Cooperative Learning: Teory, Research, and Practice. USA: Boston Allyn and Bacon.

Sulistyo, G. H. (2007). Ujian Nasional (UN): Harapan, Tantangan, dan Peluang. WACANA, 9(1), 79-106.

Team. (n.d.). Crocodile. Retrieved from http://www.crocodile-elips.com

Tilaar, A. L. F. (2014). Effect of Cooperative Learning Model Type of Team Assisted Individualization ( TAI) and the Performance Assessment of Learning Achievement to Linear Program Course. International Journal of Science and Engineering Investigations, 3(24), 25-29.

Tinungki, G. M. (2015). The Role of Cooperative Learning Type Team Assisted Individualization to Improve the Students' Mathematics Communication Ability in the Subject of Probability Theory. Journal of Education and Practice, 6(32), 27-31.

Vitria, L. N., \& Utami, B. (2014). Penerapan Metode Pembelajaran Kooperatif Team Assisted Individualization ( TAI ) Dilengkapi Handout Untuk Meningkatkan Kualitas Proses Dan Prestasi Belajar Siswa Pada Materi Larutan Peyangga Kelas XI IPA 4 SMAN 2 Karanganyar. Jurnal Pendidikan Kimia (JPK), 3(4), 59-65.

Yuniar. (2013). Mutu madarasah dan profesionalisme guru: tuntutan di era globalisasi. TA'DIB, XVIII(1), 135161. 